\title{
The Memory of the Past: the Achaemenid Legacy in the Arsakid Period
}

\begin{abstract}
The Achaemenid Empire, established by Cyrus the Great, provided a model looked up to by subsequent empires on the territory of Iran and the Middle East, including the empires ruled by Alexander of Macedonia, the Seleukids, and the Arsakids. Achaemenid patterns were eagerly imitated by minor rulers of Western Asia, including Media Atropatene, Armenia, Pontos, Kappadokia and Kommagene. The Arsakids harked back to Achaemenids, but their claims to the Achaemenid descendance were sporadic. Besides, there were no genealogical links between the Arsakids and Achaemenid satraps contrary to the dynastic patterns common in the Hellenistic Middle East.
\end{abstract}

Keywords: Iran, Cyrus the Great, Achaemenids, Arsakids, Achaemenid legacy

In this article I shall try to explain why some rulers of the Arsakid period associated their dynasty with the Achaemenids and what the context was of such declarations. The focus of this study is on the kings of Parthia from Arsakes I (248-211 B.C.) to Phraates IV (37-3/2 B.C.).

The Achaemenids established the world's first universal empire, spanning territories on three continents - Asia, Africa, and (temporary) Europe. The power of the Persians was founded by Cyrus the Great (559-530 B.C.), eulogised by the Iranians, Jews, Babylonian priests, and Greeks as well, who managed to make a not very numerous people inhabiting the lands along the Persian Gulf masters of an empire stretching from Afghanistan to the Aegean Sea, giving rise to the largest state of those times.

The Achaemenid state grew at an astounding rate under Cyrus' successors Kambyses, and Darius I. In the course of about four decades from 550 to 510 B.C., it attained a maximum extent from Egypt and Libya to the Valley of the Indus (Pakistan) and Syrdarya (Uzbekistan), from Macedonia and Thrace in Europe to the Persian Gulf. In many respects the Achaemenids inherited the legacy of the Iranian Medes and other peoples of the Ancient East (Babylonia, Elam, Urartu, 


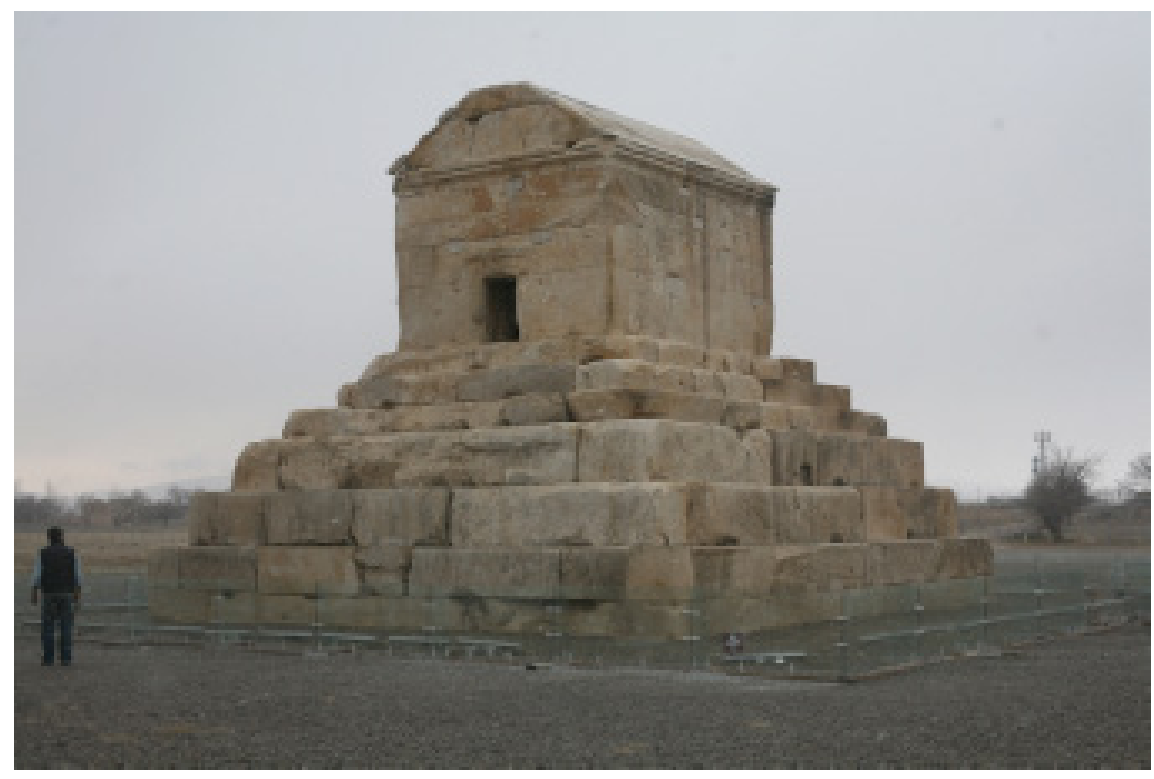

Fig. 1. Tomb of Cyrus II the Great at Pasargadai. Iran (Photo: M.J. Olbrycht)

and Assyria). ${ }^{1}$ Their vast state, furnished with a good administrative structure, a developed economy, and magnificent royal residences at Pasargadai, Persepolis, Susa, Ekbatana, and Babylon, provided a reference and model looked up to by subsequent empires on the territory of Iran: the empires ruled by Alexander, ${ }^{2}$ the Seleukids, ${ }^{3}$ and the Arsakids. Moreover, Achaemenid patterns were imitated by minor rulers of Western Asia, including Media Atropatene, Armenia, Pontos, Kappadokia and Kommagene. ${ }^{4}$

${ }^{1}$ M. Waters, Ancient Persia, Cambridge 2014.

2 M.J. Olbrycht, Aleksander Wielki i świat irański Rzeszów 2004; idem, Macedonia and Persia, [in:] Blackwell Companion to Ancient Macedonia, eds. J. Roisman, I. Worthington, Malden-Oxford 2010, pp. 342-369; idem, 'An Admirer of Persian Ways:' Alexander the Great's Reforms in Parthia-Hyrcania and the Iranian Heritage, [in:] Excavating an Empire. Achaemenid Persia in Longue Durée, eds. T. Daryaee, A. Mousavi, K. Rezakhani, Costa Mesa 2013, pp. 37-62.

${ }^{3}$ Idem, Creating an Empire: Iran and Middle Asia in the Policy of Seleucus I, [in:] Central Asia from the Achaemenids to the Timurids, ed. V.P. Nikonorov, Sankt-Petersburg 2005, pp. 231-235; idem, Iranians in the Diadochi Period, [in:] After Alexander. The Time of the Diadochi (323-281 BC), eds. V. Alonso Troncoso, E.M. Anson, Oxford-Oakville 2013, pp. 159-182; P. Panitschek, Die Seleukiden als Erben des Achämenidenreiches, Frankfurt am Main 2016.

${ }^{4}$ See: J. Wolski, Les Achéménides et les Arsacides. Contribution à l'histoire de la formation des traditions iraniennes, "Syria" 1966, no. 43, pp. 63-89; idem, L'idéologie monarchique chez les Parthes, [in:] Centro di ricerche e di documentazione sull'antichità classica. Atti VIII (1976-1977): Studi vari di storia greca, ellenistica e romana, Milano 1977, pp. 223-235; P. Panitschek, Zu den genealogischen konstruktionen der Dynastien von Pontos und Kappadokien, "Rivista di storia dell'antichità" 1987/1988, no. 17/18, pp. 73-95; idem, Zur Darstellung der Alexander-und Achaemenidennachfolge als politische Programme in kaiserzeitlichen Quellen, "Klio" 1990, no. 72, pp. 457-492; M.J. Olbrycht, Parthian King's Tiara-Numismatic Evidence and Some Aspects of Arsacid Political Ideology, "Notae Numismaticae" 1997, no. 2, pp. 27-65; idem, Mithrades VI Eurator and Iran, [in:] Mithriades VI and the Pontic 
Regarded as representatives of the next stage in imperial rule - after the glorious Achaemenids - the Seleukids were one of the chief points of reference looked up to by local dynasties, and they were often associated with Alexander of Macedonia. ${ }^{5}$ In many respects, the figure of Alexander was united with the Seleukids as one genealogical point of reference. ${ }^{6}$

Arsakids' references to Achaemenid traditions can be seen already under Arsakes I (248-211 B.C.) and Arsakes II (211-190 B.C.), such as in the use of the diadem and the soft rulers' tiara (kyrbasia). ${ }^{7}$ The Iranian title krny (*kārana-) used by Arsakes I definitely derives from Achaemenid tradition. ${ }^{8}$ As another mark of continuity, the Zoroastrian custom was maintained of establishing a coronation fire in Asaak, in clear reference to the Achaemenids (Isidoros of Charax, Stathmoi 11). ${ }^{9}$

The fire altar belonged to central motifs in the kingly iconography of the Achaemenids, and as such it was revived in Persis in Arsakid times, and later in the Sasanian period. A fire altar appears on Parthian coins under Phraates IV, Phraatakes, Artabanos II, and Vologases III. ${ }^{10}$
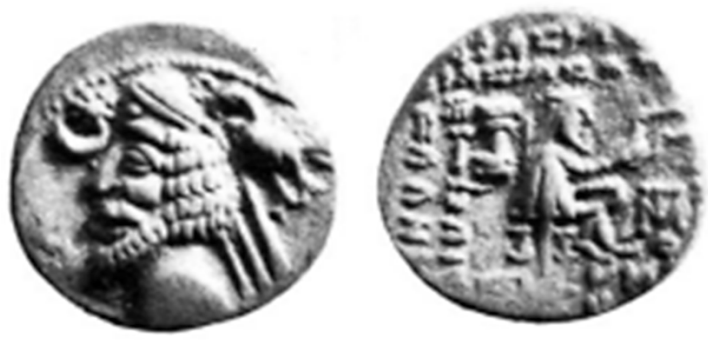

Fig. 2. Bronze coin of Phraates IV (c. 37-3 B.C. $)^{11}$

Kingdom, ed. J.M. Hoejte, Aarhus 2009, pp. 163-190; idem, The Shaping of Political Memory: Cyrus the Great and the Achaemenids in the Royal Ideologies of the Seleucid and Parthian Periods, [in:] Cyrus the Great. Life and Lore, ed. M. Rahim Shayegan, Boston-Cambridge-London 2018, pp. 198-220.

${ }_{5}^{5}$ M.J. Olbrycht, Creating an Empire..., pp. 231-235; idem, Iranians in the Diadochi Period. pp. 159-182.

${ }^{6}$ In antiquity, the Seleukid era was usually ascribed to Alexander. See: E. Bickerman, Time-reckoning, [in:] Cambridge History of Iran, vol. 3(2): The Seleucid, Arsacid and Sasanid Periods, ed. E. Yarshater, Cambridge 1983.

${ }^{7}$ Cf. J. Gaslain, Le bachlik d'Arsace Ier ou la représentation du nomade-roi, "Bulletin of Parthian and Mixed Oriental Studies", no. 1, 2005, pp. 9-30.

${ }^{8}$ M.J. Olbrycht, The titulature of Arsaces I, king of Parthia, "Parthica. Incontri di culture nel mondo antico" 2013, no. 15, pp. 63-74.

${ }^{9}$ On Iranian and specifically Achaemenid traditions in Arsakid ideology, see: J. Wolski, Les Achéménides..., pp. 63-89; M.J. Olbrycht, Parthian King's Tiara..., Teil 2, Bd. 9 , pp. 42-44; idem, 'An Admirer of Persian Ways:' '.., pp. 37-62; J. Wolski, Iran and Rom. Versuch einer historischen Wertung der gegenseitigen Beziehungen, [in:] ANRW, Berlin-New York, II 9, pp. 204-205; R. Shayegan, Arsacids and Sasanians. Political Ideology in Post-Hellenistic and Late Antique Persia, Cambridge 2011, pp. passim.

${ }^{10}$ Phraates IV: S51.49; S52.40; S54.9, S53.18; Phraatakes: S57.16; Artabanos II: S63.22, S63.13; Osroes I: S80.11 (?); Vologases III: S78.13, S78.15. See also V. Curtis, The Iranian Revival in the Parthian Period, [in:] The Age of the Parthians, Series: "Idea of Iran", vol. 2, eds. V. Curtis, S. Stewart, London 2007, pp. 7-25.

${ }^{11}$ S54.9 var. Photo after: BMC Parthia, p. 127, 227; plate 22, no. 11. 

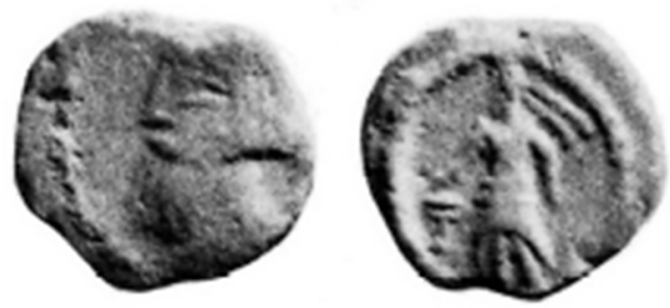

Fig. 3. Bronze coin of Artabanos II (c. A.D. 8-39/40) ${ }^{12}$

The ancient sources emphasize the significance of the very name of Arsakes (Just. 41.5.6; 41.5.8; Amm. 23.6.5). Ammianus Marcellinus (23.6.2-6) compares the Roman title of Augustus to the meaning of the name Arsakes. Justin 41.5.5-6 juxtaposes Arsakes with Cyrus, Alexander, and Romulus. The Parthians did not intend merely to commemorate the name of the dynasty's founder Arsakes (Parthian Aršak), but to transform the name into a title binding on the successors of Arsakes I. ${ }^{13}$

Arsakes/Aršak was a personal name used by some Achaemenids. Artaxerxes II (404-359 B.C.) bore the name Aršak and it was probably him whom some Arsakids considered the forefather of the dynasty. ${ }^{14}$ The name is transmitted in

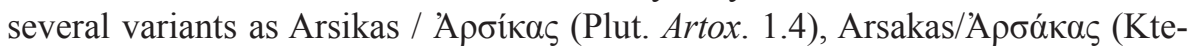

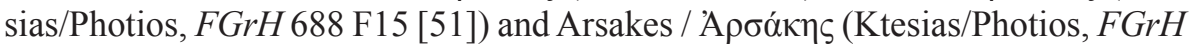

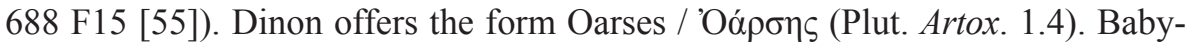
lonian sources give the form Aršu, mirrored in Greek sources as Arses / 'A It seems that the form Aršak is a hypocoriston from Old Persian * Řs $\bar{s}-{ }^{15}$ This assumption is confirmed by the evidence of OGIS 392 inscription from Kommagene which lists the names Artaxerxes and Arsakes.

The kings of Kommagene of the $1^{\text {st }}$ century B.C., closely linked to the Parthian empire by way of political and marital connections, harked back both to the Achaemenids and to Alexander and the Seleukids. King Antiochos I of Kommagene (70-36 B.C.) refers to the "two very fortunate roots" of his ancestry (Nomos, line 30-31) pointing to "Hellenes and Persians". ${ }^{16}$ The terraces of Nemrud Dağ 1 bristled with stelae bearing the names of Antiochos' forefathers. The sequence of

12 S63.22. Photo after: BMC Parthia, p. 172, 111; plate 27, no. 21.

13 More on this in: J. Gaslain, Arsaces I, the First Arsacid King? Some Remarks on the Nature of Early Parthian Power, [in:] Central Asia from the Achaemenids to the Timurids: Archaeology, History, Ethnology, Culture, ed. V.P. Nikonorov, St. Petersburg 2005, p. 222; M.J. Olbrycht, The titulature of Arsaces $I$...

14 On the name Arsakes/Arses for Artaxerxes II, see Plut. Artox. 1-2. Cf. R. Schmitt, Achaemenid Throne-Names, “Annali dell'Istituto Orientale di Napoli” 1982, no. 42, pp. 83-95, esp. 92; P. Briant, From Cyrus to Alexander: a History of the Persian Empire, transl. by P. Daniels, Winona Lake 2002, pp. 589-590, 986; C. Binder, Plutarchs Vita des Artaxerxes: Ein historischer Kommentar, Göttinger Forum für Altertumswissenschaft. Beihefte N.F. 1, Berlin-New York 2008, pp. 96-98.

15 For details, see: R. Schmitt, Achaemenid..., p. 92; C. Binder, op. cit., pp. 97-98.

16 Full text of the Nomos offers H. Waldmann, Die kommagenischen Kultreformen unter Konig Mithradates I. Kallinikos und seinem Sohne Antiochos I, Leiden 1973, pp. 62-71. 
his paternal ancestors begins with the Great King Darius I and goes up to Mithradates Kallinikos; the group of his maternal ancestors embraces Alexander the Great, Seleukos I, and ends with his mother, Laodike Thea, who was the daughter of the Seleukid king Antiochos VIII Grypos. ${ }^{17}$ Actually, the founder of the satrapal dynasty was Orontes I, the satrap of Armenia, who married a daughter of Artaxerxes II called Rhodogune. ${ }^{18}$ It is noticeable that Rhodogune is identified

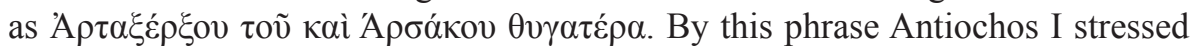
his descendance from Artaxerxes II as Achaemenid king but at the same time he seems to have alluded to his links to the alleged forefather of the Arsakids.

Fig. 4. One of Achaemenid ancestors of Antiochos of Kommagene (70-36 B.C.). Nemrud Dağı (Turkey)

(Photo: M.J. Olbrycht)

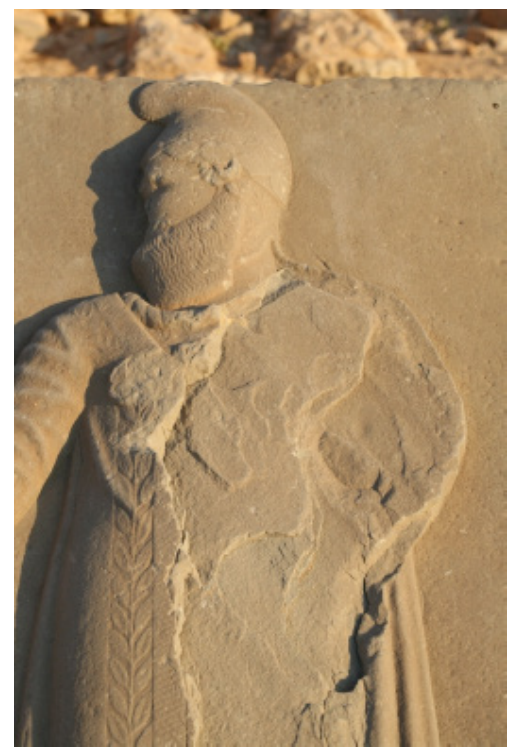

Arrian, epitomized by Photios (Parthika 1.2 Roos = Photios, cod. 58, ed. Henry), considers the Parthians to have been a "Scythian race", which had long been under the yoke of Macedonia, and revolted under the brothers Arsakes and Tiridates accompanied by five accomplices. Synkellos (Ekloga, pp. 539-540 ed. Dindorf $=$ p. 343 ed. Mosshammer) connects Arsakes and Tiridates with Persians, including with Artaxerxes, "king of the Persians", and states that

a certain Arsakes and Teridates [Tiridates], brothers tracing their lineage from Artaxerxes king of the Persians, were satraps of the Bactrians at the time of the Macedonian

${ }_{17}$ On the ancestors of Antiochos I of Kommagene, see: W. Messerschmidt, Die Ahnengalerie des Antiochos I. von Kommagene. Ein Zeugnis fur die Geschichte des östlichen Hellenismus, [in:] Gottkönige am Euphrat. Neue Ausgrabungen und Forschungen in Kommagene, ed. J. Wagner, Mainz am Rhein 2000, pp. 37-43; M. Facella, La dinastia degli Orontidi nella Kommagene ellenistico-romana, Pisa 2006, pp. 270-279, 291-4; eadem, Darius and the Achaemenids in Kommagene, [in:] Organisation des pouvoirs et contacts culturels dans les pays de l'empire achéménide, "Persika", 14, eds. P. Briant, M. Chauveau, 2009, pp. 379-414.

${ }^{18}$ Xen. An. 2.4.8; Plut. Artox. 27; OGIS 392; see M. Schottky, Media Atropatene und Gross-Armenien in hellenistischer Zeit, Bonn 1989, pp. 80-81. 
Agathokles, the Persian eparch. According to Arrian, this Agathokles fell in love with Teridates, one of the brothers, and was eagerly laying a snare for the young man. But failing utterly, he was killed by him and his brother Arsakes. Arsakes then became king of the Persians, after whom the kings of the Persians were known as 'Arsakidai'. ${ }^{19}$

Synkellos' account is confused and contains legendary elements like a conspicuous love story. Moreover, there is no trace of the existence of an early Arsakid king named Tiridates in any classical source other than Arrian-Photios and Synkellos (and derivative accounts), nor does this name appear on known Parthian ostraca as a royal name. ${ }^{20}$ Still it cannot be excluded that Synkellos's source, aware of a connection between the Arsakids and the Achaemenid king named Artaxerxes, may be reliable. Present in both traditions are legendary themes which clearly echo Herodotos. And so, the rebellion is sparked off by a tyrant's (satrap's) attempt at an aristocrat, and the history is built in much the same way as that of the overthrow of the Peisistratides in Athens. The number of seven conspirators mirrors exactly the Persian plot against Gaumata, who elevated Darius I to power (Hdt. 3.71 ff.). ${ }^{21}$

Ties between the Arsakids and the Achaemenids need not be fictitious. Crucial is the circumstance that the Arsakids did not perceive themselves as the continuators of a satrapal lineage from Achaemenid times contrary to the (largely historical) common claims held by the post-Achaemenid dynasties in Atropatene, Armenia, Pontos, Kappadokia and Kommagene. In Parthia there are no traces of a direct dynastic continuity between Arsakes I and the Achaemenids or an Achaemenid satrap. A connection between the Arsakids and the Achaemenids may have resulted from a possible marital alliance between Artaxerxes II (404359 ) and a Dahaean ruler in the steppes of Central Asia (Syrdarya Basin, borderland of Sogdiana). The founder of the Parthian empire, Arsakes I, was a "Scythian", or a nomad, one of the steppe-inhabiting Dahae. This tribe had been in the sphere of Achaemenid power from the $5^{\text {th }}$ century B.C. at least. In Alexander's time, the Dahae actively supported Darius III, and then Bessos-Artaxerxes and Spitamenes in opposing Alexander of Macedonia. ${ }^{22}$ Not impossibly, under Artaxerxes II some Achaemenid princess was married off to a Dahaean ruler, thus creating a blood relation between the Dahaean elite and the Achaemenids. We know that Artaxerxes II carried out active marital policies in his empire - he married one of his daughters Rhodogune to Orontes, satrap of Armenia. Such alliances are probable in the case of steppe rulers of Central Asia too. Contacts between the Achaemenids and peoples of Central Asia were multi-faceted. This

19 Translation by W. Adler, P. Tuffin, The Chronography of George Synkellos: A Byzantine Chronicle of Universal History from the Creation, Oxford 2002.

${ }^{20}$ V.A. Livshits, Parfianskaja onomastika, Sankt-Petersburg 2010, p. 156.

${ }^{21}$ Such themes are indicated by, among others, J. Wolski, L'Empire des Arsacides, “Acta Iranica”, 32, Lovanii 1993, pp. 56-57; idem, Seleucid and Arsacid Studies. A Progress Report on Developments in Source Research, Kraków 2003, pp. 23.

${ }^{22}$ M.J. Olbrycht, Die Beziehungen der Steppennomaden Mittelasiens zu den hellenistischen Staaten (bis zum Ende des 3. Jahrhunderts vor Chr.), [in:] Hellenismus. Beiträge zur Erforschung von Akkulturation und politischer Ordnung in den Staaten des hellenistischen Zeitalters, ed. B. Funck, Tübingen 1996, pp. 147-169. 
is visible in historical events ${ }^{23}$ and recent archaeological discoveries in western Kazakhstan and Southern Urals region. Finds from Filippovka point to the possibility of "diplomatic" marriages between nomadic rulers of the Southern Urals area and Achaemenid princesses. ${ }^{24}$ The Dahae, wandering between the Syrdarya basin and the Southern Urals steppes in Achaemenid times, must have played a significant role in nomadic-Achaemenid mutual relations.

It seems that not incidentally the name of an Artaxerxes was given to a royal vineyard mentioned in the Parthian documents of the $1^{\text {st }}$ century B.C. discovered at Nisa. The Nisan documents mention a series of vineyards: gwtrzkn (Gōtarzakān), לrtbnwkn(y) (Artabānukān), mtrdtkn(y) (Mihrdātakā), prhtkn (Frahātakān), and pryptykn(y) (Friyapatikān). These designations are derived from the names of the $2^{\text {nd }}$ and $1^{\text {st }}$-century B.C. kings of Parthia, starting from Phriapatios/Friyapat. There is also a mention of a vineyard called לrthšrkn (Artaxšahrakān), most probably in honour of Artaxerxes II, an Achaemenid monarch regarded as an ancestor of the Arsakids. The names of the vineyards correspond to the names of the temples to which they purveyed their produce. ${ }^{25}$ There are no records of a vineyard named after Arsakes/Aršak, but this name occurs five time in the archive of Nisa, three time in connection with a coronation. ${ }^{26}$ Religious worship was certainly practised at Nisa, since we know of the presence of magi and the Lord of Fire there. ${ }^{27}$

Justin (41.5.5-6) compares Arsakes with Cyrus, Alexander, and Romulus. Cyrus was the founder of the Achaemenid empire, a figure celebrated in Iran and beyond. But Arsakes' state lasted twice as long, and in less favorable political conditions (confrontation with powerful Rome), than was true of Achaemenid Persia. Another figure from Justin's list, Alexander, was appreciated not only in Rome's antique tradition, but by some Iranians, too. While his conquests changed the face of the world, he was nevertheless unable to build a state that would last.

A hundred years after Arsakes' subjugation of Khorasan Mithradates I's (165133/2 B.C.) conquests turned the Arsakid state into an empire stretching from Bactria to Babylonia and Southern Caucasia, defeating the Seleukids and local

${ }^{23}$ See: ibidem, pp. 148-158; M.J. Olbrycht, Persia Beyond the Imperial Frontiers: the Nomads of the South Ural Region versus the Near East, "Anabasis. Studia Classica et Orientalia" 2015, no. 6, pp. 257-275.

${ }^{24}$ M.J. Olbrycht, Persia Beyond the Imperial Frontiers..., pp. 257-275; M. Treister, L. Yablonsky, Einflüsse der achämenidischen Kultur im südlichen Uralvorland (5.-3. Jh. v. Chr.), "Ancient Toreutics and Jewellery in Eastern Europe", 5, Wien 2013, pp. 313-315. For new findings and conclusions regarding the contacts between Central Asian nomads and Achaemenid Iran, see also Th. Stöllner, Z. Samašev (eds.), Unbekanntes Kasachstan - Archäologie im Herzen Asiens: Katalog zur Ausstellung des Deutschen Bergbau-Museums Bochum, Bochum 2013, pp. 715-731.

${ }^{25}$ R. Schmitt, Parthische Sprach- und Namenüberlieferung aus arsakidischer Zeit, [in:] Das Partherreich und seine Zeugnisse. The Arsacid Empire: Sources and Documentation, "Historia. Einzelschriften", 122, ed. J. Wiesehöfer, Stuttgart 1998, p. 170.

${ }^{26}$ A. Bader, Parthian ostraka from Nisa: some historical data, [in:] Convegno internazionale sul tema: La Persia e l'Asia Centrale da Alessandro al X secolo, Accademia Nazionale dei Lincei. Atti del Convegni Lincei 127, Roma 1996, p. 255.

${ }^{27}$ Ibidem, p. 271. 
rulers. ${ }^{28}$ A significant political reform occured after Parthian victories in Central Asia and on Iran's eastern frontiers, when Mithradates II (122-87 B.C.) adopted the Old Achaemenid title of King of Kings. The title (written in Greek as BA $\Sigma \mathrm{I} \Lambda \mathrm{E} \Omega \Sigma$ $\mathrm{BA} \Sigma \mathrm{I} \Lambda \mathrm{E} \Omega \mathrm{N}$ ) first appeared on Parthian coins of type $\mathrm{S} 27$ which includes silver drachms and bronze fractions (S 27.1-13 and S 27.28). ${ }^{29}$

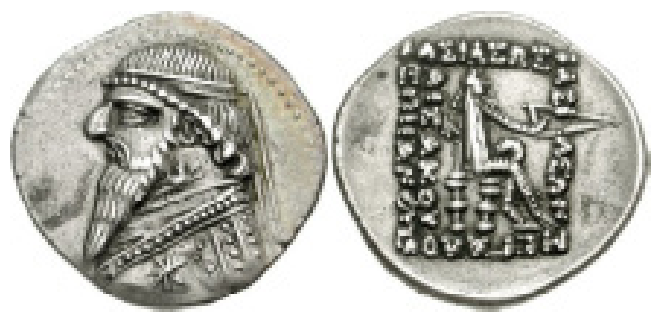

Fig. 5. Drachm of Mithradates II (122-87) with the title of King of Kings ${ }^{30}$

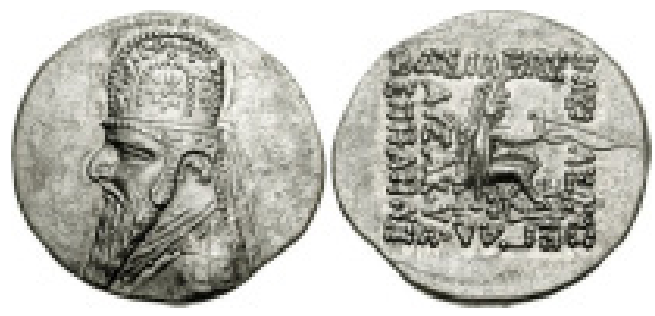

Fig. 6. Drachm of Mithradates II (122-87) with the title of King of Kings ${ }^{31}$

The oldest undisputed evidence of the title of King of Kings is the Babylonian diary no. 110 'rev'. i' (= 346-347), dated to 111 B.C. (year 201 of the Seleukid era), and the Goal Year text no. 93 flake 3', dated to the years 112-111 B.C. (year 200 of the Seleukid era). ${ }^{32}$ The title of King of Kings became ubiquitous throughout the Parthian Empire. About a hundred years had passed since the death of Arsakes I, and in that time the Arsakid state had become not just the propagandistic pretender, but the real political and cultural heir to the Achaemenid legacy. ${ }^{33}$

The epithet King of Kings became an almost inseparable part of Arsakid titulature. Mithradates II excellently capitalized on his own political and military

28 See: M.J. Olbrycht, Mithradates I of Parthia and His Conquests up to 141 B.C., [in:] Hortus Historiae. Studies in Honour of Professor Jozef Wolski on the 100th Anniversary of His Birthday, eds. M. Dzielska et al., Kraków 2010, pp. 229-245.

$29 \mathrm{~S}=\mathrm{D}$. Sellwood, An Introduction to the Coinage of Parthia, London 1980.

30 Type 27.5. After http://www.cngcoins.com/Coin.aspx?CoinID=153315 (access: 27.04.2019). Triton XIII (5 Jan 2010), lot 571. Ex R. Gonnella Collection (Peus 388, 1 November 2006), lot 353.

31 Type S 28.1. After: http://www.cngcoins.com/Coin.aspx?CoinID=153317 (access: 27.04.2019). Triton XIII (5 Jan 2010), lot 573.

32 A.J. Sachs, H. Hunger, Astronomical Diaries arul Related Texts from Babylonia, vol. 6, "Goal Year Texts", Vienna 2006, no. 93 flake 3'. See: R. Shayegan, op. cit., p. 43, n. 22.

33 J. Wolski, Les Achéménides..., p. 74. 
successes, but also on his predecessors' strenuous efforts. In little more than 100 years, the Arsakids built and stabilized a vast empire embracing lands from Armenia to Bactria and Sogdiana and from the Syrian frontier (Dura Europos) to Arachosia.

Media, the richest land on the Iranian Plateau, with its metropolis of Ekbatana, played a decisive role in Parthian policies from Mithradates I (165-133/132). ${ }^{34}$ Once they had taken control of Media, the Arsakids were quick to install themselves in the iconography of the Holy Mountain of Bisotun/Behistun. Several Parthian royal reliefs were placed at Bisotun next to the inscription of Darius in the holy Zoroastrian area. ${ }^{35}$

What is the picture of the Arsakids against the background of many sovereigns claiming their lineage connected to Achaemenids? The Arsakids were busy building up an empire and only occasionally needed to look back to ancient traditions in terms of genealogical constructs: for them political realities took precedence over ideology. Moreover, their main reference point remained Arsakes I. As they ruled in the stalwart and populous lands of Iran, the Arsakids were not forgetful of the Achaemenid legacy. Arsakes had acceded to the throne around three generations after the death of Darius III, when the memory of the Achaemenids and their grandeur must still have been vivid.

The Arsakids harked back to the Achaemenids in many respect, but their claims to the Achaemenid descendance were sporadic. In Arsakid Parthia there is no trace of the existence of any great clans originating from Achaemenid satrapal families. The major Parthian clans like the Sūrēn and Kārin ${ }^{36}$ must have been actually newly established great families without particular links to the Achaemenid period magnates including the Hydarnids, Orontids, or the Phrataphernes' line.

\section{Bibliography}

Adler W., Tuffin P., The Chronography of George Synkellos: A Byzantine Chronicle of Universal History from the Creation, Oxford 2002.

$A N R W=$ Temporini H., Haase W. (eds.), Aufstieg und Niedergang der römischen Welt, Berlin 1972.

Bader A., Parthian ostraka from Nisa: some historical data, [in:] Convegno internazionale sul tema: La Persia e l'Asia Centrale da Alessandro al X secolo, Accademia Nazionale dei Lincei. Atti del Convegni Lincei 127, Roma 1996, pp. 251-276.

Bickerman E., Time-reckoning, [in:] Cambridge History of Iran, vol. 3(2): The Seleucid, Arsacid and Sasanid Periods, ed. E. Yarshater, Cambridge 1983, pp. 778-791.

Binder C., Plutarchs Vita des Artaxerxes: Ein historischer Kommentar, Göttinger Forum für Altertumswissenschaft. Beihefte N.F. 1, Berlin-New York 2008.

${ }^{34}$ Media's wealth: Strab. 11.13.7; Amm. 23.3.5; 23.6.29; 23.6.31.

${ }_{35}$ M. Boyce, F. Grenet, A History of Zoroastrianism. Volume III: Zoroastrianism under Macedonian and Roman Rule, Leiden 1991, pp. 91-94.

${ }^{36}$ M.J. Olbrycht, Parthia and Nomads of Central Asia. Elements of Steppe Origin in the Social and Military Developments of Arsakid Iran, [in:] Mitteilungen des SFB Differenz und Integration, vol. 5: Militär und Staatlichkeit, ed. I. Schneider, Halle-Saale 2003, pp. 69-109. 
BMC Parthia = Wroth W., A Catalogue of the Greek Coins in the British Museum: the Coins of Parthia, London 1903.

Boyce M., Grenet F., A History of Zoroastrianism. Volume III: Zoroastrianism under Macedonian and Roman Rule, Leiden 1991.

Briant P., From Cyrus to Alexander: a History of the Persian Empire, transl. by P. Daniels, Winona Lake 2002.

Curtis V., The Iranian Revival in the Parthian Period, [in:] The Age of the Parthians, Series: "Idea of Iran", vol. 2, eds. V. Curtis, S. Stewart, London 2007, pp. 7-25.

Facella M., La dinastia degli Orontidi nella Commagene ellenistico-romana, Pisa 2006.

Facella M., Darius and the Achaemenids in Commagene, [in:] Organisation des pouvoirs et contacts culturels dans les pays de l'empire achéménide, "Persika", 14, eds. P. Briant, M. Chauveau, 2009, pp. 379-414.

Gaslain J., Arsaces I, the First Arsacid King? Some Remarks on the Nature of Early Parthian Power, [in:] Central Asia from the Achaemenids to the Timurids: Archaeology, History, Ethnology, Culture, ed. V.P. Nikonorov, St. Petersburg 2005, pp. 221-224.

Gaslain J., Le bachlik d'Arsace Ier ou la représentation du nomade-roi, "Bulletin of Parthian and Mixed Oriental Studies" 2005, no. 1, pp. 9-30.

Livshits V.A., Parfianskaja onomastika, Sankt-Petersburg 2010.

Messerschmidt W., Die Ahnengalerie des Antiochos I. von Kommagene. Ein Zeugnis fur die Geschichte des östlichen Hellenismus, [in:] Gottkönige am Euphrat. Neue Ausgrabungen und Forschungen in Kommagene, ed. J. Wagner, Mainz am Rhein 2000, pp. 37-43.

OGIS = Dittenberger W., Orientis Graeci Inscriptiones Selectae. Supplementum Sylloges Inscriptionum Graecarum, Leipzig 1903-1905.

Olbrycht M.J., Die Beziehungen der Steppennomaden Mittelasiens zu den hellenistischen Staaten (bis zum Ende des 3. Jahrhunderts vor Chr.), [in:] Hellenismus. Beiträge zur Erforschung von Akkulturation und politischer Ordnung in den Staaten des hellenistischen Zeitalters, ed. B. Funck, Tübingen 1996, pp. 147-169.

Olbrycht M.J., Parthian King's Tiara - Numismatic Evidence and Some Aspects of Arsacid Political Ideology, "Notae Numismaticae" 1997, no. 2, pp. 27-65.

Olbrycht M.J., Parthia and Nomads of Central Asia. Elements of Steppe Origin in the Social and Military Developments of Arsakid Iran, [in:] Mitteilungen des SFB Differenz und Integration, vol. 5: Militär und Staatlichkeit, ed. I. Schneider, HalleSaale 2003, pp. 69-109.

Olbrycht M.J., Aleksander Wielki i świat irański, Rzeszów 2004.

Olbrycht M.J., Creating an Empire: Iran and Middle Asia in the Policy of Seleucus I, [in:] Central Asia from the Achaemenids to the Timurids, ed. V.P. Nikonorov, SanktPetersburg 2005, pp. 231-235.

Olbrycht M.J., Mithradates VI Eupator and Iran, [in:] Mithridates VI and the Pontic Kingdom, ed. J.M. Hoejte, Aarhus 2009, pp. 163-190.

Olbrycht M.J., Macedonia and Persia, [in:] Blackwell Companion to Ancient Macedonia, eds. J. Roisman, I. Worthington, Malden-Oxford 2010, pp. 342-369.

Olbrycht M.J., Mithradates I of Parthia and His Conquests up to 141 B.C., [in:] Hortus Historiae. Studies in Honour of Professor Jozef Wolski on the 100th Anniversary of His Birthday, eds. M. Dzielska et al., Kraków 2010, pp. 229-245. 
Olbrycht M.J., Iranians in the Diadochi Period, [in:] After Alexander. The Time of the Diadochi (323-281 BC), eds. V. Alonso Troncoso, E.M. Anson, Oxford-Oakville 2013, pp. 159-182.

Olbrycht M.J., 'An Admirer of Persian Ways:' Alexander the Great's Reforms in Parthia-Hyrcania and the Iranian Heritage, [in:] Excavating an Empire. Achaemenid Persia in Longue Durée, eds. T. Daryaee, A. Mousavi, K. Rezakhani, Costa Mesa 2013, pp. 37-62.

Olbrycht M.J., The titulature of Arsaces I, king of Parthia, "Parthica. Incontri di culture nel mondo antico" 2013, no. 15, pp. 63-74.

Olbrycht M.J., Persia Beyond the Imperial Frontiers: the Nomads of the South Ural Region versus the Near East, "Anabasis. Studia Classica et Orientalia” 2015, no. 6, pp. 257-275.

Olbrycht M.J., The Shaping of Political Memory: Cyrus the Great and the Achaemenids in the Royal Ideologies of the Seleucid and Parthian Periods, [in:] Cyrus the Great. Life and Lore, ed. M. Rahim Shayegan, Boston-Cambridge-London 2018, pp. 198-220.

Panitschek P., Zu den genealogischen konstruktionen der Dynastien von Pontos und Kappadokien, "Rivista di storia dell'antichità" 1987/1988, no. 17/18, pp. 73-95.

Panitschek P., Zur Darstellung der Alexander- und Achaemenidennachfolge als politische Programme in kaiserzeitlichen Quellen, "Klio" 1990, no. 72, pp. 457-492.

Panitschek P., Die Seleukiden als Erben des Achämenidenreiches, Frankfurt am Main 2016.

Sachs A.J., Hunger H., Astronomical Diaries and Related Texts from Babylonia, vol. 6, "Goal Year Texts", Vienna 2006.

Schmitt R., Achaemenid Throne-Names, "Annali dell'Istituto Orientale di Napoli" 1982, no. 42, pp. 83-95.

Schmitt R., Parthische Sprach- und Namenüberlieferung aus arsakidischer Zeit, [in:] Das Partherreich und seine Zeugnisse. The Arsacid Empire: Sources and Documentation, "Historia. Einzelschriften", 122, ed. J. Wiesehöfer, Stuttgart 1998, pp. 163204.

Schottky M., Media Atropatene und Gross-Armenien in hellenistischer Zeit, Bonn 1989. Sellwood D., An Introduction to the Coinage of Parthia, London 1980.

Shayegan R., Arsacids and Sasanians. Political Ideology in Post-Hellenistic and Late Antique Persia, Cambridge 2011.

Stöllner Th., Samašev Z. (eds.), Unbekanntes Kasachstan - Archäologie im Herzen Asiens: Katalog zur Ausstellung des Deutschen Bergbau-Museums Bochum, Bochum 2013.

Treister M., Yablonsky L., Einflüsse der achämenidischen Kultur im südlichen Uralvorland (5.-3. Jh. v. Chr.), "Ancient Toreutics and Jewellery in Eastern Europe", 5, Wien 2013.

Waldmann H., Die kommagenischen Kultreformen unter Konig Mithradates I. Kallinikos und seinem Sohne Antiochos I, Leiden 1973.

Waters M., Ancient Persia, Cambridge 2014.

Wolski J., Les Achéménides et les Arsacides. Contribution à l'histoire de la formation des traditions iraniennes, "Syria" 1966, no. 43, pp. 63-89.

Wolski J., Iran und Rom. Versuch einer historischen Wertung der gegenseitigen Beziehungen, [in:] $A N R W$, Berlin-New York, Teil 2, Bd. 9, pp. 195-214. 
Wolski J., L'idéologie monarchique chez les Parthes, [in:] Centro di ricerche e di documentazione sull'antichità classica. Atti VIII (1976-1977): Studi vari di storia greca, ellenistica e romana, Milano 1977, pp. 223-235.

Wolski J., L'Empire des Arsacides, “Acta Iranica”, 32, Lovanii 1993.

Wolski J., Seleucid and Arsacid Studies. A Progress Report on Developments in Source Research, Kraków 2003. 